\title{
Energy and protein requirements of crossbred (Holstein $\times$ Gyr) growing bulls
}

\author{
D. B. Oss, ${ }^{*}$ F. S. Machado,† T. R. Tomich,† L. G. R. Pereira,† M. M. Campos,† M. M. D. Castro, ${ }^{*}$ T. E. da Silva, ${ }^{*}$ \\ and M. I. Marcondes*1 \\ *Federal University of Viçosa, Animal Science Department, Viçosa, MG, Brazil, 36570-900 \\ †Brazilian Agricultural Research Corporation, Embrapa Dairy Cattle, Juiz de Fora, MG, Brazil, 36038-330
}

\section{ABSTRACT}

The objective of this study was to estimate the energy and protein requirements of crossbred (Holstein $\times$ Gyr) growing bulls. Twenty-four 10-mo-old bulls [initial body weight $(\mathrm{BW})=184 \pm 23.4 \mathrm{~kg}$ ] were used in a comparative slaughter trial. Six bulls were slaughtered at the beginning of the experiment as the reference group, to estimate initial empty body weight (EBW) and energy and protein contents of the remaining animals. The remaining bulls were assigned to a completely randomized design with 3 levels of dry matter intake and 6 replicates. The levels of dry matter intake were $1.2 \%$ of $\mathrm{BW}, 1.8 \%$ of $\mathrm{BW}$, and ad libitum to target orts equal to $5 \%$ of the total amount that was fed. The remaining bulls were slaughtered at the end of the experiment. The bulls were fed a diet consisting of $59.6 \%$ corn silage and $40.4 \%$ concentrate on a dry matter basis. The equation that determined the relationship between $\mathrm{EBW}$ and $\mathrm{BW}$ was $\mathrm{EBW}=(0.861 \pm 0.0031) \times \mathrm{BW}$. The relationship between empty body gain (EBG) and average daily gain (ADG) was demonstrated by the following equation: $\mathrm{EBG}=(0.934 \pm 0.0111) \times \mathrm{ADG}$. Net energy for maintenance $\left(\mathrm{NE}_{\mathrm{M}}\right)$ was $74.8 \pm 2.89 \mathrm{kcal} / \mathrm{kg}$ of $\mathrm{EBW}^{0.75}$ per day, and metabolizable energy for maintenance $\left(\mathrm{ME}_{\mathrm{M}}\right)$ was $120.8 \mathrm{kcal} / \mathrm{kg}$ of $\mathrm{EBW}^{0.75}$ per day. The detected efficiency of use of metabolizable energy for maintenance $\left(k_{\mathrm{m}}\right)$ was $61.9 \%$. The equation used to estimate net energy for gain $\left(\mathrm{NE}_{\mathrm{G}}\right)$ was as follows: $\mathrm{NE}_{\mathrm{G}}$ $=(0.049 \pm 0.0011) \times \mathrm{EBW}^{0.75} \times \mathrm{EBG}^{0.729 \pm 0.0532}$. The efficiency of use of metabolizable energy for gain $\left(k_{\mathrm{g}}\right)$ was $35.7 \%$. The metabolizable protein for maintenance $\left(\mathrm{MP}_{\mathrm{M}}\right)$ was $3.05 \mathrm{~g} / \mathrm{kg}$ of $\mathrm{BW}^{0.75}$. The equation used to estimate net protein requirements for gain $\left(\mathrm{NP}_{\mathrm{G}}\right)=$ $(87.138 \pm 65.1378 \times \mathrm{EBG})+[(40.436 \pm 21.3640) \times$ $\left.\mathrm{NE}_{\mathrm{G}}\right]$. The efficiency of use of metabolizable protein for gain $(k)$ was $35.7 \%$. We concluded that the estimates of energy and protein requirements presented herein are

Received May 6, 2016.

Accepted December 14, 2016.

${ }^{1}$ Corresponding author: marcosinaciomarcondes@gmail.com more appropriate than the National Research Council dairy cattle model and the Brazilian BR-CORTE system to balance the diets of crossbred (Holstein $\times$ Gyr) growing bulls.

Key words: Bos indicus, growth, Gyr, Holstein, maintenance

\section{INTRODUCTION}

Experiments that seek to estimate the nutrient requirements of specific breeds may be justified due to the need to expand current databases to support new meta-analysis and updates and validation of more consistent models. Bos indicus and Bos indicus $\times$ Bos taurus cattle are commonly used in dairy and beef production in tropical regions. Bos indicus are used for crossbreeding (Bos indicus $\times$ Bos taurus) because of their ability to resist hot and humid weather and intense sunshine, to tolerate parasites, and to utilize poor-quality forages (Turner, 1980).

The dairy Gyr (Bos indicus) breed has mainly been selected for milk yield and it is found throughout countries in South America, including Brazil. The desirable characteristics of dairy Gyr have increased interest in the breed and subsequent exportation of semen to other countries in Africa and Central and South America (Pereira et al., 2013). In Brazil, for example, about 70\% of milk production comes from crossbred (Holstein $\times$ Zebu) cows, with Holstein $\times$ Gyr being the most common crossbreed (Embrapa, 2009).

The Nutrient Requirements of Dairy Cattle (NRC, 2001 ) is the most widely used system to balance the diets of dairy cattle. However, the equations to estimate energy and protein requirements by this system for growing animals are from research involving mostly British beef breeds (Garrett, 1980) and are the same as those adopted by the Nutrient Requirements of Beef Cattle (NRC, 1996).

In attempt to provide information regarding the nutrient requirements of cattle that are used in tropical regions (mainly Nellore and Nellore $\times$ Bos taurus), Brazilian researchers published nutrient requirements 
for beef cattle, the BR-CORTE system (Valadares Filho et al., 2010). However, there is still a gap in knowledge regarding nutrient requirements of Holstein $\times$ Gyr crossbreds.

Therefore, we believe that determining the nutrient requirements of crossbred cattle (Holstein $\times$ Gyr) and providing the appropriate knowledge to balance diets is necessary to avoid supplying excessive or insufficient nutrients to these animals (Marcondes and Silva, 2015). In addition, information about the requirements of Holstein $\times$ Gyr cattle is scarce in the literature (Almeida et al., 2001; Rotta et al., 2013). The objective of this study was to estimate the energy and protein requirements for the maintenance and gain of crossbred (Holstein $\times$ Gyr) growing bulls.

\section{MATERIALS AND METHODS}

Animal care procedures throughout the study followed protocols approved by the Conselho de Ética no Uso de Animais de Produção (CEUAP/UFV; process number 044/2012) of the Universidade Federal de Viçosa. The experiment was conducted at the Multiuse Complex on Livestock Bioefficiency and Sustainability at the Embrapa Gado de Leite (Embrapa Dairy Cattle), in Coronel Pacheco, MG, Brazil, from August 2013 to February 2014.

\section{Animals, Diet, and Experimental Design}

Twenty-four $7 / 8$ Holstein $\times 1 / 8$ Gyr crossbred bulls of $293 \pm 21.3 \mathrm{~d}$ age (initial $\mathrm{BW}=184 \pm 23.4 \mathrm{~kg}$ ) were used. Initially, all bulls were treated for ectoparasites and endoparasites (Ivomec, Paulina, São Paulo, Brazil). The bulls were randomly subdivided into 4 groups of 6 animals at the beginning of the experiment. One group was designated as the baseline reference group, and was slaughtered at the beginning of the experiment to estimate the initial empty body weight (EBW) and initial body energy and protein content of the other animals. The 3 remaining groups were fed at 3 levels of DMI: (1) 1.2\% of BW (close to maintenance level); (2) $1.8 \%$ of $\mathrm{BW}$; or (3) ad libitum to target orts equal to $5 \%$ of the total amount that was fed for about 25 wk until final slaughter. These treatments were chosen with the intention of achieving variability in $\mathrm{ME}$ and MP intakes (MEI and MPI) to obtain a betteradjusted model. One animal from the ad libitum group had to be removed from the experiment due to health issues. The bulls were housed in a tiestall system with free access to water.

The diet was formulated according to BR-CORTE (Valadares Filho et al., 2010) for a hypothetical ADG
Table 1. Composition of the concentrate and experimental diet (g/ $\mathrm{kg}$; DM basis)

\begin{tabular}{lcc}
\hline Ingredient & Concentrate & Diet \\
\hline Corn silage & 679 & 596 \\
Ground corn & 248 & 274 \\
Soybean meal & 35 & 100 \\
Mineral mix & 24 & 14 \\
Urea & 14 & 10 \\
Limestone & 14 & 6 \\
\hline
\end{tabular}

${ }^{1}$ Composition: Ca, $200 \mathrm{~g} / \mathrm{kg}$ min; P, $60 \mathrm{~g} / \mathrm{kg} ; \mathrm{Mg}, 20 \mathrm{~g} / \mathrm{kg} ; \mathrm{K}, 35 \mathrm{~g} /$ $\mathrm{kg} ; \mathrm{S}, 20 \mathrm{~g} / \mathrm{kg} ; \mathrm{Na}, 70 \mathrm{~g} / \mathrm{kg}$; Co, $15 \mathrm{mg} / \mathrm{kg} ; \mathrm{Cu}, 700 \mathrm{mg} / \mathrm{kg} ; \mathrm{Mn}, 1,600$ $\mathrm{mg} / \mathrm{kg} ; \mathrm{Zn}, 2,500 \mathrm{mg} / \mathrm{kg} ;$ Se, 19 mg/kg; I, 40 mg/kg.

of $1.2 \mathrm{~kg} / \mathrm{d}$ and average BW of $240 \mathrm{~kg}$. Throughout the study, the bulls were fed a diet consisting of corn silage and concentrate (59.6:40.4, DM basis) once daily. The concentrate was composed of soybean meal, ground corn, urea, mineral mix, and limestone (Table 1). The feed ingredients of the concentrate were collected for analysis at the time the concentrate was manufactured. Representative samples of silage, concentrate, and orts were collected daily and pooled monthly for chemical analysis (Table 2). The composite sample of orts each month was proportional to the weight (DM basis) from each day. The DM feed that was offered and refused were weighed to determine the total daily DMI.

The samples were analyzed for contents of DM (AOAC, 1990; method 930.15), ash (AOAC, 1990; method 924.05), CP (AOAC, 1990; method 984.13), ether extract with petroleum ether (AOAC, 1990; method 920.39), NFC (Sniffen et al., 1992), and NDF (Van Soest et al., 1991) with heat-stable amylase and sodium sulfite and expressed exclusive of residual ash. Gross energy was determined by using an adiabatic calorimeter (model C-5000, Labcontrol IKA, São Paulo, SP, Brazil). The bulls were weighed at 15-d intervals at $0730 \mathrm{~h}$ before feeding $(0830 \mathrm{~h})$ to calculate ADG. The animals from the 3 remaining groups were slaughtered at the end of the experiment to determine their final

Table 2. Chemical composition of the ingredients used in experimental diets ( $\mathrm{g} / \mathrm{kg}$ unless otherwise noted; DM basis)

\begin{tabular}{lrrr}
\hline Item & $\begin{array}{c}\text { Corn } \\
\text { silage }\end{array}$ & Concentrate & Diet \\
\hline $\mathrm{DM}$ & 307.2 & 891.8 & 543.4 \\
$\mathrm{OM}$ & 947.7 & 924.8 & 938.4 \\
$\mathrm{CP}$ & 77.3 & 252.5 & 148.1 \\
Ether extract & 24.4 & 35.1 & 28.8 \\
$\mathrm{NDF}^{1}$ & 464.6 & 145.8 & 335.8 \\
$\mathrm{NFC}^{2}$ & 381.4 & 491.3 & 425.8 \\
Gross energy (Mcal/kg) & 4.3 & 4.3 & 4.3 \\
\hline
\end{tabular}

${ }^{1}$ Analyzed with heat-stable amylase and sodium sulfite and expressed exclusive of residual ash.

${ }^{2}$ Calculated as $100-(\mathrm{NDF}+\mathrm{CP}+$ ash $)$. 
EBW and final body energy and protein contents. The experiment lasted for 173,171 , and $168 \mathrm{~d}$ for the $1.2 \%$ of $\mathrm{BW}, 1.8 \%$ of $\mathrm{BW}$, and ad libitum groups, respectively. All animals in these groups were slaughtered on the day after the end of feeding period.

\section{Digestibility}

Digestibility was evaluated at 2 time points during the study: at 2 mo after the feeding period was initiated ( $1 \mathrm{~d}$ after the initial reference slaughter) and about 2 mo before the feeding period was finalized ( $1 \mathrm{~d}$ before the final slaughter). Total feces and urine were collected for 3 consecutive days from all animals in the remaining groups (Rotta et al., 2014). At the end of each collection day, the feces of each animal were weighed. The feces were sampled after homogenization. The samples were then weighed, dried in a forced-ventilation oven $\left(55^{\circ} \mathrm{C}\right)$ for $72 \mathrm{~h}$, and ground through a 1-mm screen (Wiley mill; A. H. Thomas, Philadelphia, PA). One composite sample per animal, based on DM weight, for every collection day was prepared for chemical analysis. The same chemical analyses that were performed for the experimental diet were performed for feces to calculate the DM, nutrients, and energy digestibility coefficients. The ME content was determined by multiplying the digestible energy by 0.82 (NRC, 1996).

Urine collection was performed by using rubber collection funnels attached to the bulls. Each funnel had a hose to carry urine to an individual 20-L polyethylene container containing $400 \mathrm{~mL}$ of $20 \% \mathrm{H}_{2} \mathrm{SO}_{4}$ to reduce $\mathrm{N}$ and purine derivative losses. Acidity was monitored daily to maintain a $\mathrm{pH}<4.0$. Also, each container was kept immersed in ice. After each 24-h collection day, the total urine that was excreted was weighed and measured. The contents of each container were homogenized and a $50-\mathrm{mL}$ sample was taken and stored at $-20^{\circ} \mathrm{C}$ for later laboratory analysis.

The $\mathrm{N}$ content was analyzed in feed ( $\mathrm{N}$ intake), feces (fecal $\mathrm{N}$ ), and in the initial and final bodies. Digested nitrogen was calculated as the difference between $\mathrm{N}$ intake and fecal $\mathrm{N}$. The retained nitrogen was calculated as the difference between $\mathrm{N}$ content in the final body and initial body.

The MPI was calculated as the sum of the true microbial digestible protein and the digestible rumen-undegradable protein intakes. Microbial protein production was calculated from purine derivative excretion, which is the sum of total allantoin and uric acid excretions, and was obtained by multiplying their concentrations by the daily urinary volume (Chen and Gomes, 1992). The true fraction and digestibility that were adopted for microbial protein were $80 \%$ and $80 \%$, respectively
(NRC, 2001). The RUP intake was calculated as the difference between the CP intake and RDP intake. The digestibility that was adopted for RUP was $80 \%$. The RDP intake was calculated while taking into account an efficiency of $\mathrm{N}$ utilization in the rumen of $90 \%$ (NRC, 2001).

\section{Slaughter and Sampling}

All bulls were fasted for $16 \mathrm{~h}$ to obtain the shrunk body weight (SBW) before slaughter. Bulls from the same group were slaughtered on the same day. Bulls were slaughtered by using captive bolt stunning followed by bleeding. Blood was sampled at the moment of bleeding to avoid sampling after coagulation. After bleeding, the gastrointestinal tract was removed and all of the digesta contained within were removed by washing. The heart, lungs, liver, spleen, kidneys, the fat around the kidney, pelvis, and heart (KPH fat), diaphragm, mesentery, tails, trimmings, and cleaned gastrointestinal tracts were weighed together. The carcasses, head, leather, limbs, and blood were weighed to determine the EBW.

The rumen, reticulum, omasum, abomasum, small and large intestines, KPH fat, mesentery, liver, heart, kidneys, lung, tongue, spleen, diaphragm, esophagus, trachea, tails, and reproductive tract of each bull were homogenized in an industrial cutter for $20 \mathrm{~min}$. A sample then was taken to compose a sample of organs and viscera.

After removing the hide, the head and limbs were ground in a bone crusher for 20 min. A sample was taken to compose a sample of head and limbs. The hide of each animal was sampled in 2 parts to represent the shoulder, 3 parts to represent the dorsal line, 2 parts to represent the ventral line, 2 parts to represent the rear, 1 part to represent each foot, and 1 part to represent the head, which altogether represented the entire hide (Costa e Silva et al., 2015). All parts of the hide were minced into small $\left(2-\mathrm{cm}^{2}\right)$ pieces. A sample then was taken to compose a sample of hide.

After slaughter, the carcasses of each animal were split into 2 half-carcasses that were chilled at $4^{\circ} \mathrm{C}$ for $18 \mathrm{~h}$. After the 18-h period, the left half-carcass was ground in a bone crusher for $20 \mathrm{~min}$ and transferred to an industrial cutter to be homogenized for $20 \mathrm{~min}$. After homogenization, a sample was taken to compose a sample of carcass.

All samples from each animal (blood, organs and viscera, head and limbs, hide and carcass) were previously lyophilized before they were ground in a knife mill $(2 \mathrm{~mm})$ and in an industrial blender while adding liquid nitrogen. The liquid nitrogen was used to fa- 
cilitate grinding while avoiding sample conglomeration, which may occur due to the fat content. A composite sample of the whole animal was made by using relative individual proportion (DM basis) in the EBW. It was homogenized by using an industrial blender as previously described, for later laboratory analysis.

The DM, CP, ether extract, ash, and gross energy contents were determined for the composite sample of the whole animal by following the methods described above for experimental diet ingredients and feces.

\section{Procedures to Verify Relationships Among Live, Shrunk, and Empty BW and Between ADG and Empty Body Gain}

To verify the relationship among live, shrunk, and empty BW, a linear regression was performed as follows:

$$
\mathrm{EBW} \text { or } \mathrm{SBW}=\beta_{0}+\left(\beta_{1} \times \mathrm{SBW} \text { or } \mathrm{BW}\right),
$$

where EBW is empty BW $(\mathrm{kg})$, SBW is shrunk BW $(\mathrm{kg}), \mathrm{BW}$ is live $\mathrm{BW}(\mathrm{kg})$, and $\beta_{0}$ and $\beta_{1}$ are regression parameters.

To verify the relationship between ADG and empty body gain (EBG, $\mathrm{kg} / \mathrm{d}$ ), a linear regression was performed as follows:

$$
\mathrm{EBG}=\beta_{0}+\left(\beta_{1} \times \mathrm{ADG}\right),
$$

where all terms are as previously defined.

\section{Procedures to Estimate Energy Requirements}

To estimate the net energy requirements for maintenance $\left(\mathrm{NE}_{\mathrm{M}}\right)$, a nonlinear exponential model was used to describe the relationship between heat production $\left(\mathbf{H P} ; \mathrm{Mcal} / \mathrm{kg}\right.$ of EBW ${ }^{0.75}$ ) and MEI (Mcal $/ \mathrm{kg}$ of $\mathrm{EBW}^{0.75}$ ) according to the following model (Lofgreen and Garrett, 1968):

$$
\mathrm{HP}=\beta_{0} \times \mathrm{e}^{\beta_{1} \times \mathrm{MEI}} .
$$

Under this model, $\beta_{0}$ represents the $\mathrm{NE}_{\mathrm{M}}$.

By the iterative method, the point where MEI equals HP can be determined, and this point was considered the $\mathrm{ME}$ requirement for maintenance $\left(\mathbf{M E}_{\mathbf{M}}\right)$.

The HP (Mcal $/ \mathrm{kg}$ of $\mathrm{EBW}^{0.75}$ ) was calculated as the difference between MEI (Mcal/kg of $\mathrm{EBW}^{0.75}$ ) and retained energy (RE; Mcal $/ \mathrm{kg}$ of $\mathrm{EBW}^{0.75}$ ). The MEI was determined as previously described and RE was calculated as the difference between the final energy content and initial energy content in the EBW.
The efficiency of use of $\mathrm{ME}_{\mathrm{M}}\left(\boldsymbol{k}_{\mathrm{m}}\right)$ was obtained from the ratio of $\mathrm{NE}_{\mathrm{M}}$ to $\mathrm{ME}_{\mathrm{M}}(\mathrm{NRC}, 1996)$ :

$$
k_{\mathrm{m}}=\frac{\mathrm{NE}_{\mathrm{M}}}{\mathrm{ME}_{\mathrm{M}}} .
$$

To predict the net energy requirements for gain $\left(\mathrm{NE}_{\mathrm{G}}\right)$, the following model was used (NRC, 1984):

$$
\mathrm{RE}=\beta_{0} \times \mathrm{EBW}^{0.75} \times \mathrm{EBG}^{\beta_{1}},
$$

where RE is the retained energy (Mcal/d), EBW ${ }^{0.75}$ is the metabolic empty BW, EBG is the empty body weight gain $(\mathrm{kg} / \mathrm{d})$, and $\beta_{0}$ and $\beta_{1}$ are regression parameters. Under this model, $\mathrm{RE}$ represents the $\mathrm{NE}_{\mathrm{G}}$.

To estimate the ME requirements for gain $\left(\mathbf{M E}_{\mathbf{G}}\right)$, it was necessary to estimate the efficiency of use of ME for gain $\left(\boldsymbol{k}_{\mathrm{g}}\right)$, which was estimated as the slope of the regression of $\mathrm{RE}$ on the $\mathrm{MEI}_{\mathrm{G}}$ (Ferrell and Jenkins, 1998):

$$
\mathrm{RE}=\beta_{0}+\left(\beta_{1} \times \mathrm{MEI}_{\mathrm{G}}\right)
$$

where $\mathrm{RE}$ is retained energy (Mcal $/ \mathrm{kg}$ of $\mathrm{EBW}^{0.75}$ per day), $\mathrm{MEI}_{\mathrm{G}}$ is $\mathrm{ME}$ intake for gain (Mcal $/ \mathrm{kg}$ of $\mathrm{EBW}^{0.75}$ per day), which was estimated as the difference between total MEI (Mcal $/ \mathrm{kg}$ of $\mathrm{EBW}^{0.75}$ per day) and $\mathrm{MEI}_{\mathrm{M}}$ (Mcal/kg of $\mathrm{EBW}^{0.75}$ per day) as described above, and $\beta_{0}$ and $\beta_{1}$ are regression parameters. Under this model, $\beta_{1}$ represents the $k_{\mathrm{g}}$.

The $\mathrm{ME}_{\mathrm{G}}$ was then obtained from the relationship between $\mathrm{NE}_{\mathrm{G}}$ and $\mathrm{ME}_{\mathrm{G}}$ :

$$
\mathrm{ME}_{\mathrm{G}}=\frac{\mathrm{NE}_{\mathrm{G}}}{k_{\mathrm{g}}} .
$$

\section{Procedures to Estimate Protein Requirements}

Metabolizable protein for maintenance $\left(\mathbf{M P}_{\mathbf{M}}\right)$ was estimated by the relationship between the intercept $\left(\beta_{0}\right)$ from the linear regression between MPI $(\mathrm{g} / \mathrm{d})$ and EBG $(\mathrm{kg} / \mathrm{d})$ as follows (Wilkerson et al., 1993):

$$
\mathrm{MPI}=\beta_{0}+\left(\beta_{1} \times \mathrm{EBG}\right),
$$

The $\mathrm{MP}_{\mathrm{M}}\left(\mathrm{g} / \mathrm{kg}\right.$ of $\left.\mathrm{BW}^{0.75}\right)$ was then estimated by the relationship between $\beta_{0}$ and average metabolic BW $\left(\mathrm{BW}^{0.75}\right)$ as follows (NRC, 1996):

$$
\mathrm{MP}_{\mathrm{M}}=\frac{\beta_{0}}{\mathrm{BW}^{0.75}},
$$


where $\beta_{0}$ is the parameter determined from Equation [8].

The net protein requirements for gain $\left(\mathbf{N P}_{\mathrm{G}}\right)$ were estimated by using a model involving EBG $(\mathrm{kg} / \mathrm{d})$ and RE (Mcal/d), as follows (NRC, 1996; Valadares Filho et al., 2010):

$$
\mathrm{RP}=\left(\beta_{0} \times \mathrm{EBG}\right)+\left(\beta_{1} \times \mathrm{RE}\right),
$$

where RP is retained protein $(\mathrm{g} / \mathrm{d})$.

The efficiency of use of MP for gain $(\boldsymbol{k})$ was estimated based on the linear relationship between retained nitrogen $(\mathbf{R N}, \mathrm{g} / \mathrm{d})$ and MPI $(\mathrm{g} / \mathrm{d})$ :

$$
\mathrm{RN}=\beta_{0}+\left(\beta_{1} \times \mathrm{MPI}\right) .
$$

Under Equation [11], $\beta_{1}$ is the efficiency of use of MP for gain $(k)$.

The relationship between $\mathrm{NP}_{\mathrm{G}}\left(\mathrm{g} / \mathrm{kg}\right.$ of $\mathrm{EBW}^{0.75}$ per day) and $k$ was used to estimate MP requirements for gain $\left(\mathbf{M P}_{\mathbf{G}}, \mathrm{g} / \mathrm{kg}\right.$ of $\mathrm{EBW}^{0.75}$ per day):

$$
\mathrm{MP}_{\mathrm{G}}=\frac{\mathrm{NP}_{\mathrm{G}}}{k}
$$

\section{Statistical Analysis}

The DM, nutrients, and energy intake and digestibility coefficients were analyzed by using PROC MIXED of SAS (SAS Inst. Inc., Cary, NC). The model included the fixed effects of treatment, digestibility trial, and treatment $\times$ digestibility trial; period of digestibility trial was treated as a repeated measure. A level of 0.05 was used as the critical level of probability, and the Tukey-Kramer test was used to detect differences between treatments.
The models described above were fit as linear and nonlinear models built by PROC MIXED and PROC NLIN of SAS, respectively. The data were analyzed as nonlinear models and were adjusted by the GaussNewton method. For all models, outliers were removed when the studentized residuals were greater than $|2|$, and 0.05 was used as the critical level of probability to verify the significance of the models parameters.

\section{RESULTS}

\section{Dry Matter, Nutrients, and Energy Intake and Digestibility Coefficients}

The DM, nutrients, and energy intake were different among treatments (Table 3). The $1.2 \%$ of BW treatment resulted in greater DM, nutrients, and energy digestibility coefficients compared with the $1.8 \%$ of BW and ad libitum treatments. The $1.8 \%$ of BW treatment resulted in greater $\mathrm{DM}, \mathrm{OM}, \mathrm{NFC}$, and gross energy digestibility coefficients compared with the ad libitum treatment (Table 4).

\section{Relationships Among Live, Shrunk, and Empty BW and Between ADG and EBG}

The equation determined from the relationship between SBW and BW was [mean square error $(\mathrm{MSE})=$ $\left.19.009 ; \mathrm{R}^{2}=0.997\right]$

$$
\mathrm{SBW}=(0.976 \pm 0.0061) \times \mathrm{BW} .
$$

The equation determined from the relationship between $\mathrm{EBW}$ and $\mathrm{SBW}$ was $\left(\mathrm{MSE}=51.179 ; \mathrm{R}^{2}=0.942\right)$

$$
\mathrm{EBW}=(0.882 \pm 0.0061) \times \mathrm{SBW} .
$$

Table 3. Least squares means, standard error, and significance of effects for nutrient (kg) and energy (Mcal) daily intakes according to levels of DM supply

\begin{tabular}{lcccc}
\hline & \multicolumn{3}{c}{ DMI level } \\
\cline { 2 - 4 } Item & $\begin{array}{c}1.2 \% \text { of BW } \\
(\mathrm{n}=6)\end{array}$ & $\begin{array}{c}1.8 \% \text { of BW } \\
(\mathrm{n}=6)\end{array}$ & $\begin{array}{c}\text { Ad libitum } \\
(\mathrm{n}=5)\end{array}$ & SE \\
\hline DMI & $2.20^{\mathrm{c}}$ & $4.24^{\mathrm{b}}$ & $7.66^{\mathrm{a}}$ & 0.584 \\
OM intake & $2.06^{\mathrm{c}}$ & $3.97^{\mathrm{b}}$ & $7.18^{\mathrm{a}}$ & 0.361 \\
CP intake & $0.33^{\mathrm{c}}$ & $0.64^{\mathrm{b}}$ & $1.19^{\mathrm{a}}$ & 0.056 \\
Ether extract intake & $0.06^{\mathrm{c}}$ & $0.12^{\mathrm{b}}$ & $0.23^{\mathrm{a}}$ & 0.011 \\
NDF intake & $0.72^{\mathrm{c}}$ & $1.38^{\mathrm{b}}$ & $2.47^{\mathrm{a}}$ & 0.133 \\
NFC intake & $0.94^{\mathrm{c}}$ & $1.83^{\mathrm{b}}$ & $3.30^{\mathrm{a}}$ & 0.161 \\
TDN intake & $1.64^{\mathrm{c}}$ & $2.95^{\mathrm{b}}$ & $5.07^{\mathrm{a}}$ & 0.270 \\
Gross energy intake & $9.38^{\mathrm{c}}$ & $18.08^{\mathrm{b}}$ & $32.67^{\mathrm{a}}$ & 1.645 \\
Digestible energy intake & $6.91^{\mathrm{c}}$ & $12.38^{\mathrm{b}}$ & $21.19^{\mathrm{a}}$ & 1.552 \\
ME intake & $5.67^{\mathrm{c}}$ & $10.15^{\mathrm{b}}$ & $17.37^{\mathrm{a}}$ & 1.273 \\
\hline
\end{tabular}

${ }^{\mathrm{a}-\mathrm{c}}$ Means within a row followed by different letters differ $(P \leq 0.05)$. 
Table 4. Least squares means, standard error, and significance of effects for nutrient ( $\mathrm{g} / \mathrm{kg}$ ) and energy (kcal/ Mcal) digestibility coefficients according to levels of DM supply

\begin{tabular}{lcccc}
\hline & \multicolumn{3}{c}{ DMI level } \\
\cline { 2 - 4 } Item & $\begin{array}{c}1.2 \% \text { of BW } \\
(\mathrm{n}=6)\end{array}$ & $\begin{array}{c}1.8 \% \text { of BW } \\
(\mathrm{n}=6)\end{array}$ & $\begin{array}{c}\text { Ad libitum } \\
(\mathrm{n}=5)\end{array}$ & SE \\
\hline DM & $744^{\mathrm{a}}$ & $698^{\mathrm{b}}$ & $659^{\mathrm{c}}$ & 9.6 \\
OM & $760^{\mathrm{a}}$ & $712^{\mathrm{b}}$ & $674^{\mathrm{c}}$ & 9.3 \\
$\mathrm{CP}$ & $727^{\mathrm{a}}$ & $691^{\mathrm{b}}$ & $679^{\mathrm{b}}$ & 11.6 \\
Ether extract & $886^{\mathrm{a}}$ & $829^{\mathrm{b}}$ & $808^{\mathrm{b}}$ & 21.3 \\
NDF & $632^{\mathrm{a}}$ & $540^{\mathrm{b}}$ & $514^{\mathrm{b}}$ & 16.6 \\
NFC & $860^{\mathrm{a}}$ & $841^{\mathrm{a}}$ & $781^{\mathrm{b}}$ & 10.3 \\
Gross energy & $737^{\mathrm{a}}$ & $685^{\mathrm{b}}$ & $648^{\mathrm{c}}$ & 10.7 \\
\hline
\end{tabular}

${ }^{\mathrm{a}-\mathrm{c}}$ Means within a row followed by different letters differ $(P \leq 0.05)$.

The equation determined from the relationship between $\mathrm{BW}$ and $\mathrm{EBW}$ was $\left(\mathrm{MSE}=8.720 ; \mathrm{R}^{2}=0.972\right)$

$$
\mathrm{EBW}=(0.861 \pm 0.0031) \times \mathrm{BW} .
$$

Similarly, the intercept of the linear regression between $\mathrm{ADG}$ and EBW was not different from zero $(P=$ 0.0981 ), and the equation determined from the relationship between ADG and EBG was $(\mathrm{MSE}=0.001$; $\left.\mathrm{R}^{2}=0.973\right)$

$$
\mathrm{EBG}=(0.934 \pm 0.0111) \times \mathrm{ADG}
$$

\section{Energy and Protein Requirements}

A descriptive database of the bulls used in this study is shown in Table 5. A summary of all equations fit for estimating the total requirements of energy and protein of dairy crossbred bulls in this study is presented in Table 6.

Energy Requirements. The $\mathrm{NE}_{\mathrm{M}}$ observed in this study was $74.8 \mathrm{kcal} / \mathrm{kg}$ of $\mathrm{EBW}^{0.75}$ per day, according to the following equation $\left(\mathrm{MSE}=0.00005 ; \mathrm{R}^{2}=0.969\right)$ :

$$
\mathrm{HP}=(0.075 \pm 0.0029) \times \mathrm{e}^{(3.968 \pm 0.1597) \times \mathrm{MEI}} .
$$

Through iterative method, the $\mathrm{ME}_{\mathrm{M}}$ was $120.8 \mathrm{kcal} / \mathrm{kg}$ of $\mathrm{EBW}^{0.75}$ per day, and $k_{\mathrm{m}}$ was $61.9 \%$.

To estimate the $\mathrm{NE}_{\mathrm{G}}$, the following equation was determined $\left(\mathrm{MSE}=0.044 ; \mathrm{R}^{2}=0.991\right)$ :

$$
\begin{aligned}
\mathrm{NE}_{\mathrm{G}}= & (0.049 \pm 0.0011) \times \mathrm{EBW}^{0.75} \\
& \times \mathrm{EBG}^{(0.729 \pm 0.0532)} .
\end{aligned}
$$

\begin{tabular}{|c|c|c|c|}
\hline \multirow[b]{2}{*}{ Item } & \multicolumn{3}{|c|}{ DMI level } \\
\hline & $\begin{array}{c}1.2 \% \text { of } \mathrm{BW} \\
\quad(\mathrm{n}=6)\end{array}$ & $\begin{array}{c}1.8 \% \text { of } \mathrm{BW} \\
(\mathrm{n}=6)\end{array}$ & $\begin{array}{l}\text { Ad libitum } \\
\quad(\mathrm{n}=5)\end{array}$ \\
\hline Initial BW (kg) & $181.5 \pm 22.42$ & $187.8 \pm 29.32$ & $182.6 \pm 21.13$ \\
\hline Final BW (kg) & $190.5 \pm 24.71$ & $281.3 \pm 50.62$ & $388.2 \pm 48.77$ \\
\hline Initial empty BW (EBW; kg) & $151.6 \pm 18.73$ & $156.9 \pm 24.49$ & $152.5 \pm 17.64$ \\
\hline Final empty BW (kg) & $166.3 \pm 18.62$ & $244.6 \pm 44.43$ & $343.8 \pm 46.00$ \\
\hline $\mathrm{DMI}(\%$ of $\mathrm{BW})$ & $1.25 \pm 0.027$ & $1.90 \pm 0.034$ & $2.76 \pm 0.188$ \\
\hline $\mathrm{ADG}(\mathrm{kg} / \mathrm{d})$ & $0.05 \pm 0.061$ & $0.55 \pm 0.130$ & $1.22 \pm 0.232$ \\
\hline Empty body gain (kg/d) & $0.09 \pm 0.039$ & $0.51 \pm 0.128$ & $1.14 \pm 0.229$ \\
\hline Retained energy (kcal/kg of EBW $\mathrm{EB}^{0.75}$ ) & $10.0 \pm 3.54$ & $28.8 \pm 5.16$ & $54.8 \pm 8.45$ \\
\hline ME intake (kcal/kg of EBW ${ }^{0.75}$ ) & $133.3 \pm 5.17$ & $199.8 \pm 9.35$ & $285.0 \pm 23.14$ \\
\hline Heat production (kcal/kg of $\mathrm{EBW}^{0.75}$ ) & $123.3 \pm 4.59$ & $171.0 \pm 9.44$ & $230.1 \pm 25.12$ \\
\hline Retained protein $\left(\mathrm{g} / \mathrm{kg}\right.$ of $\left.\mathrm{EBW}^{0.75}\right)$ & $0.8 \pm 0.19$ & $2.2 \pm 0.31$ & $3.7 \pm 0.42$ \\
\hline MP intake $\left(\mathrm{g} / \mathrm{kg}\right.$ of $\left.\mathrm{EBW}^{0.75}\right)$ & $5.1 \pm 0.18$ & $8.1 \pm 0.48$ & $12.8 \pm 1.42$ \\
\hline $\mathrm{RE}_{\mathrm{f}}^{1}(\%)$ & $52.7 \pm 11.93$ & $58.1 \pm 7.51$ & $64.2 \pm 2.75$ \\
\hline $\mathrm{RE}_{\mathrm{p}}{ }^{1}(\%)$ & $47.3 \pm 11.93$ & $41.9 \pm 7.51$ & $36.1 \pm 2.75$ \\
\hline $\mathrm{EBG}_{\mathrm{p}}^{2}(\mathrm{~g} / \mathrm{kg}$ of $\mathrm{EBW})$ & $605 \pm 27.7$ & $561 \pm 28.5$ & $519 \pm 30.7$ \\
\hline $\mathrm{EBG}_{\mathrm{f}}(\mathrm{g} / \mathrm{kg}$ of EBW $)$ & $236 \pm 29.0$ & $304 \pm 44.3$ & $395 \pm 25.1$ \\
\hline
\end{tabular}

Table 5. Descriptive of the database (mean \pm SD) used to obtain the energy and protein requirements of crossbred (Holstein $\times$ Gyr) growing bulls

${ }^{1}$ Percentage of retained energy deposited as fat $\left(\mathrm{RE}_{\mathrm{f}}\right)$ and protein $\left(\mathrm{RE}_{\mathrm{p}}\right)$.

${ }^{2}$ Proportion of protein $\left(\mathrm{EBG}_{\mathrm{p}}\right)$ and fat $\left(\mathrm{EBG}_{\mathrm{f}}\right)$ in empty body gain. 


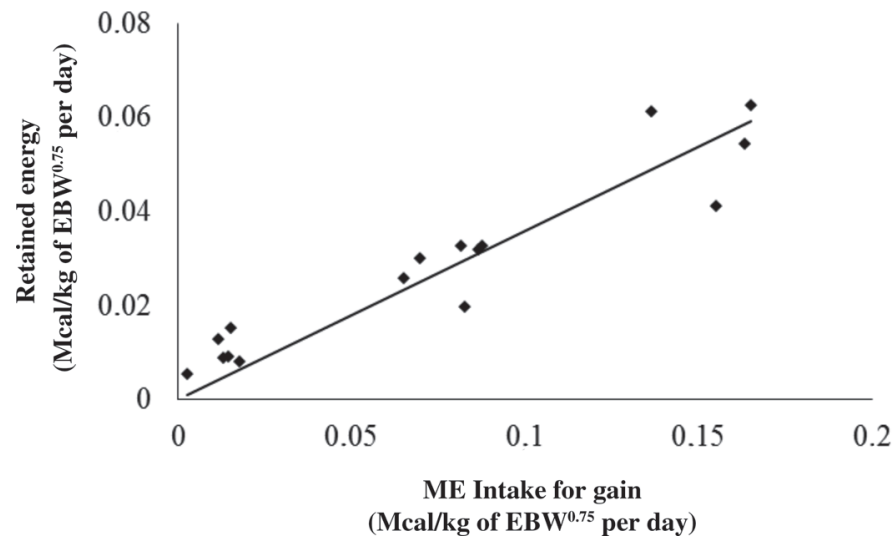

Figure 1. Relationship between retained energy (RE) and ME intake for gain $\left(\mathrm{MEI}_{\mathrm{G}}\right)$ of Holstein $\times$ Gyr crossbred yearling bulls. $\mathrm{RE}=$ $(0.357 \pm 0.0188) \times$ MEI (mean square error $\left.=0.00005 ; R^{2}=0.855\right)$, where the efficiency of use of ME for gain $\left(k_{\mathrm{g}}\right)$ is the slope of the regression.

The $k_{\mathrm{g}}$ that was observed in this study was $35.7 \%$ (Figure 1).

Protein Requirements. The parameter $\beta_{0}$ from Equation [8] was $181.0 \pm 27.8$. Thus, the equation used to estimate $\mathrm{MP}_{\mathrm{M}}$ was

$$
\mathrm{MP}_{\mathrm{M}}=\frac{181.0 \pm 27.8}{\mathrm{BW}^{0.75}}
$$

Because the average $\mathrm{BW}^{0.75}$ was $59.3 \pm 9.82 \mathrm{~kg}$, the $\mathrm{MP}_{\mathrm{M}}$ estimated in this study was $3.05 \mathrm{~g} / \mathrm{kg}$ of $\mathrm{BW}^{0.75}$ per day.

The equation to estimate $\mathrm{NP}_{\mathrm{G}}$ was $(\mathrm{MSE}=314.89$; $\left.\mathrm{R}^{2}=0.903\right)$

$$
\begin{gathered}
\mathrm{NP}_{\mathrm{G}}=[(87.138 \pm 65.4378) \times \mathrm{EBG}] \\
+\left[(40.436 \pm 21.3640) \times \mathrm{NE}_{\mathrm{G}}\right]
\end{gathered}
$$

and the $k$ observed in this study was $35.7 \%$ (Figure 2).

\section{DISCUSSION}

\section{Dry Matter, Nutrients, and Energy Intake and Digestibility Coefficients}

As anticipated, animals under a restricted DM supply compared with the ad libitum treatment presented with lower nutrients and energy intake $(P=0.001$; Table 3$)$.

The DM, OM, CP, ether extract, NDF, NFC, and energy digestibility coefficients were $12.9 \%, 12.8 \%, 7.1 \%$, $9.7 \%, 22.9 \%, 10.1 \%$, and $13.7 \%$ greater for the $1.2 \%$ of BW treatment (maintenance) compared with the ad libitum treatment. The decrease in digestibility with increased DMI was previously reported (Clark et al., 2007) and has been related in the literature to a greater ruminal digesta passage rate (Chen et al., 1992), which

\begin{tabular}{|c|c|c|}
\hline Item & Equation & Unit \\
\hline Shrunk BW (SBW) & $0.976 \times \mathrm{BW}$ & $\mathrm{kg}$ \\
\hline Empty BW (EBW) & $0.882 \times \mathrm{SBW}$ & $\mathrm{kg}$ \\
\hline EBW & $0.861 \times \mathrm{BW}$ & $\mathrm{kg}$ \\
\hline Empty body gain (EBG) & $0.934 \times \mathrm{ADG}$ & $\mathrm{kg} / \mathrm{d}$ \\
\hline \multicolumn{3}{|l|}{ Energy requirements ${ }^{1}$} \\
\hline $\mathrm{NE}_{\mathrm{M}}$ & $0.075 \times \mathrm{EBW}^{0.75}$ & $\mathrm{Mcal} / \mathrm{d}$ \\
\hline$k_{\mathrm{m}}$ & 61.9 & \\
\hline $\mathrm{ME}_{\mathrm{M}}$ & $0.121 \times \mathrm{EBW}^{0.75}$ & $\mathrm{Mcal} / \mathrm{d}$ \\
\hline $\mathrm{NE}_{\mathrm{G}}$ & $0.049 \times \mathrm{EBW}^{0.75} \times \mathrm{EBG}^{0.729}$ & $\mathrm{Mcal} / \mathrm{d}$ \\
\hline$k_{\mathrm{g}}$ & 30.8 & \\
\hline$\stackrel{\mathscr{M}}{\mathrm{M}}_{\mathrm{G}}$ & $\mathrm{NE}_{\mathrm{G}} / k_{\mathrm{g}}$ & $\mathrm{Mcal} / \mathrm{d}$ \\
\hline $\mathrm{ME}_{\mathrm{T}}$ & $\mathrm{ME}_{\mathrm{M}}+\mathrm{ME}_{\mathrm{G}}$ & $\mathrm{Mcal} / \mathrm{d}$ \\
\hline TDN & $\mathrm{ME}_{\mathrm{T}} / 0.82 / 4.409$ & $\mathrm{~kg} / \mathrm{d}$ \\
\hline \multicolumn{3}{|l|}{ Protein requirements ${ }^{2}$} \\
\hline $\mathrm{MP}_{\mathrm{M}}$ & $3.05 \times \mathrm{BW}^{0.75}$ & $\mathrm{~g} / \mathrm{d}$ \\
\hline $\mathrm{NP}_{\mathrm{G}}$ & $(87.138 \times \mathrm{EBG})+\left(40.436 \times \mathrm{NE}_{\mathrm{g}}\right)$ & $\mathrm{g} / \mathrm{d}$ \\
\hline$k$ & 35.7 & $\%$ \\
\hline $\mathrm{MP}_{\mathrm{G}}$ & $\mathrm{NP}_{\mathrm{G}} / k$ & $\mathrm{~g} / \mathrm{d}$ \\
\hline $\mathrm{MP}_{\mathrm{T}}$ & $\mathrm{MP}_{\mathrm{M}}+\mathrm{MP}_{\mathrm{G}}$ & $\mathrm{g} / \mathrm{d}$ \\
\hline $\mathrm{MicP}$ & $110 \times \mathrm{TDN}^{\mathrm{N}}$ & $\mathrm{g} / \mathrm{d}$ \\
\hline RDP & $1.11 \times \mathrm{MicP}$ & $\mathrm{g} / \mathrm{d}$ \\
\hline RUP & {$\left[\mathrm{MP}_{\mathrm{T}}-(\mathrm{MicP} \times 0.64)\right] / 0.80$} & $\mathrm{~g} / \mathrm{d}$ \\
\hline $\mathrm{CP}$ & RDP + RUP & $\mathrm{g} / \mathrm{d}$ \\
\hline
\end{tabular}

Table 6. Abstract of estimative models of energy and protein requirements of crossbred (Holstein $\times$ Gyr) growing bulls

${ }^{1} k_{\mathrm{m}}=$ efficiency of use of ME for maintenance; $k_{\mathrm{g}}=$ efficiency of use of ME for gain; $\mathrm{ME}_{\mathrm{M}}=\mathrm{ME}$ requirement for maintenance; $\mathrm{ME}_{\mathrm{G}}=\mathrm{ME}$ requirement for gain; $\mathrm{ME}_{\mathrm{T}}=$ total $\mathrm{ME}$ requirement.

${ }^{2} \mathrm{MP}_{\mathrm{M}}=\mathrm{MP}$ for maintenance; $\mathrm{NP}_{\mathrm{G}}=$ net protein requirements for gain; $k=$ efficiency of use of MP for gain; $\mathrm{MP}_{\mathrm{G}}=\mathrm{MP}$ for gain; $\mathrm{MP}_{\mathrm{T}}=$ total $\mathrm{MP}$ requirement; $\mathrm{MicP}=$ microbial protein. 
resulted in a shorter time for digestion by the microbial population in the rumen (Owens and Goetsch, 1986). When the level of intake was decreased, which occurred for the maintenance treatment $(1.2 \%$ of $\mathrm{BW})$, the retention time of particles in the rumen and the total gastrointestinal tract was greater, and the average size of ruminal and rectal particles was reduced (Doreau and Diawara, 2003).

\section{Relationships Among Live, Shrunk, and Empty BW and Between ADG and EBG}

The average ratio between SBW and EBW in this study was 0.882 , a value close to that reported by the BR-CORTE (Valadares Filho et al., 2010), which was 0.895 for beef Bos indicus cattle and beef Bos indicus $\times$ Bos taurus. However, this relationship may vary between 85 and 95\% (NRC, 1996). The NRC (2001) maintains that EBW is 0.891 of $\mathrm{SBW}$ and 0.855 of $\mathrm{BW}$.

The average ratio between ADG and EBG was 0.934, whereas the ratio reported by the BR-CORTE (Valadares Filho et al., 2010) was 0.966 for crossbred cattle (Nellore $\times$ Bos taurus) and those reported by the NRC dairy cattle (NRC, 2001) and the CSIRO (2007) systems were 0.960 and 0.917 , respectively.

\section{Energy Requirements}

Our results generated values for estimates of $\mathrm{NE}_{\mathrm{M}}$ that can deviate from estimates generated from the NRC dairy and beef cattle systems (NRC, 1996, 2001) and the BR-CORTE (Valadares Filho et al., 2010); it is possible to compare the energy and protein require-

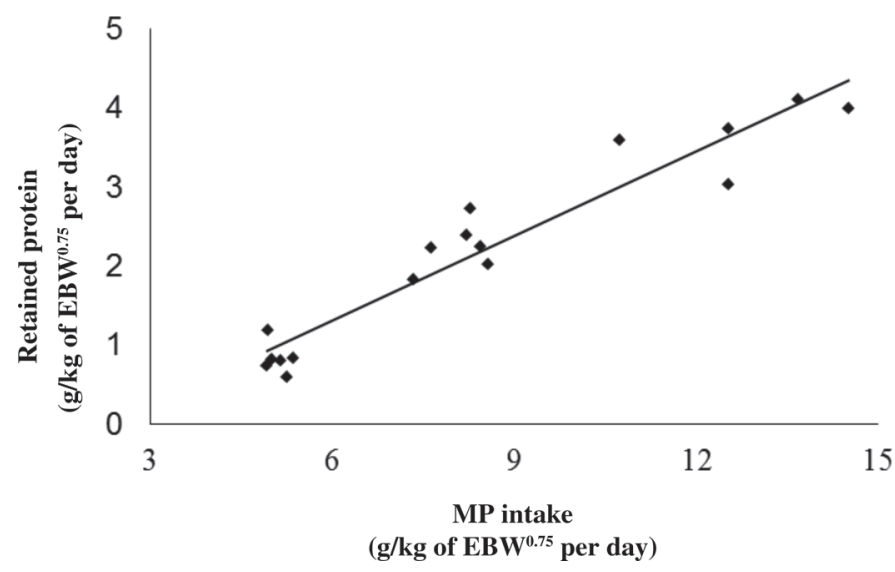

Figure 2. Relationship between retained protein (RP) and MP intake (MPI) of Holstein $\times$ Gyr crossbred yearling bulls. $\mathrm{RP}=(-0.834$ $\pm 0.2436)+(0.357 \pm 0.0271) \times \mathrm{MPI}$ (mean square error $=0.111 ; \mathrm{R}^{2}$ $=0.920)$, where the efficiency of use of MP for gain $(k)$ is the slope of the regression. ments obtained in this study with those determined by the NRC dairy cattle system (NRC, 2001) and the BR-CORTE (Valadares Filho et al., 2010) by using the available supplementary material (https://doi. org/10.3168/jds.2016-11414; referenced in Appendix). Our results suggest that the dairy crossbreeds Bos taurus $\times$ Bos indicus may diverge from the NRC model in some instances. However, further studies are needed that include both Holstein purebred and Bos taurus $\times$ Bos indicus crossbreeds so we can statistically determine those differences. Therefore, throughout the discussion, statements of similarities or differences reflect simple comparisons rather than statistical differences.

In our study, we observed an $\mathrm{NE}_{\mathrm{M}}$ of $74.8 \mathrm{kcal} / \mathrm{kg}$ of $\mathrm{EBW}^{0.75}$. The $\mathrm{NE}_{\mathrm{M}}$ requirements of beef cattle (British breeds) were estimated as $77 \mathrm{kcal} / \mathrm{kg}$ of $\mathrm{EBW}^{0.75}$ (NRC, 1996, from Lofgreen and Garrett, 1968), whereas the NRC dairy cattle model (NRC, 2001) uses a value of 80 $\mathrm{kcal} / \mathrm{kg}$ of $\mathrm{BW}^{0.75}$. The $\mathrm{NE}_{\mathrm{M}}$ requirement of Bos indicus proposed by the NRC beef cattle model (NRC, 1996) is $70 \mathrm{kcal} / \mathrm{kg}$ of $\mathrm{EBW}^{0.75}$, and that reported by the BRCORTE (Valadares Filho et al., 2010) for crossbred cattle was $74.2 \mathrm{kcal} / \mathrm{kg}$ of $\mathrm{EBW}^{0.75}$. Although the BRCORTE's database (753 animals) contained only 7 Bos indicus (Nellore) crossed with Holstein, the reported $\mathrm{NE}_{\mathrm{M}}$ is very similar to ours.

A value of $\mathrm{NE}_{\mathrm{M}}$ equal to $78.7 \mathrm{kcal} / \mathrm{kg}$ of $\mathrm{EBW}^{0.75}$ (Rotta et al., 2013) was later observed for finishing Holstein $\times$ Zebu bulls. The $\mathrm{NE}_{\mathrm{M}}$ requirements of crossbred Holstein $\times$ Gyr bulls estimated in the current study are intermediate to those observed for purebred cattle (Bos indicus or Bos taurus) and slightly lower than those indicated for growing dairy cattle by the NRC dairy cattle model (NRC, 2001).

The $\mathrm{ME}_{\mathrm{M}}$ estimated in this current study was 120.8 $\mathrm{kcal} / \mathrm{kg}$ of $\mathrm{EBW}^{0.75}$ and the $k_{\mathrm{m}}$ was $61.9 \%$, whereas another study that evaluated Holstein $\times$ Zebu cattle reported $114.2 \mathrm{kcal} / \mathrm{kg}$ of $\mathrm{EBW}^{0.75}$ and $68.9 \%$ (Rotta et al., 2013), respectively. When the $k_{\mathrm{m}}$ was calculated using an equation that takes into account the effects of $k_{\mathrm{g}}$ and EBG on $k_{\mathrm{m}}$ (Marcondes et al., 2013), the value of $k_{\mathrm{m}}$ was very close to that estimated from the bulls in this study, which was $60.6 \%$. The variability in estimates of $\mathrm{NE}_{\mathrm{M}}$ may be related partly to differences in mathematical models and the accuracy of measurements (Tedeschi et al., 2002, 2004). Also, $\mathrm{NE}_{\mathrm{M}}$ is influenced by the physiological conditions of age, sex, physical activity, and temperature (NRC, 1996). The $k_{\mathrm{m}}$ detected in this study was very similar to that recommended in the NRC beef and dairy cattle models (NRC, 1996, 2001) and numerically lower than the value recommended by BR-CORTE (Valadares Filho et al., 2010) for crossbred beef Bos taurus $\times$ Bos indicus. 
With regards to $\mathrm{NE}_{\mathrm{G}}$, the exponent of EBG observed in this study (0.729) was numerically lower than that reported by the BR-CORTE (Valadares Filho et al., 2010) for bulls (1.095) and that reported by the NRC model (NRC, 2001) for growing dairy cattle (1.097). However, the intercept for determining $\mathrm{NE}_{\mathrm{G}}$ in our study (0.049) was close to that reported by the BRCORTE (Valadares Filho et al., 2010) for bulls (0.053) but slightly lower than that reported by the NRC (NRC, 2001) for growing dairy cattle (0.064).

In this study, bulls were slaughtered at relatively low BW (Table 3) and were submitted to less energetic diets (less than $50 \%$ of concentrate in the diet). Energy increases and protein contents of gain decrease at a particular EBG with weight in a particular body size (NRC, 1984). Thus, the lower exponent of EBG indicates that, in this study, faster-growing animals had greater protein:fat ratio in the gain. Our results indicate a greater proportion of protein than fat in EBG $(\mathrm{g} / \mathrm{kg}$ of $\mathrm{EBG})$, which corroborates this result (Table 3). As occurred with $\mathrm{NE}_{\mathrm{M}}$, the $\mathrm{NE}_{\mathrm{G}}$ of crossbred Holstein $\times$ Gyr growing bulls was intermediate (Appendix) between the $\mathrm{NE}_{\mathrm{G}}$ estimated by the $\mathrm{NRC}$ beef and dairy cattle (NRC, 1996, 2001) and that of BR-CORTE (Valadares Filho et al., 2010) for growing cattle.

Naturally, the partial efficiency of energy utilization for production is lower than that for maintenance (Kleiber, 1961). The $k_{\mathrm{g}}$ observed in the current study was $35.7 \%$ (Figure 1), which is numerically lower than the $k_{\mathrm{g}}$ observed in another study $(46.3 \%)$ that evaluated Zebu $\times$ Holstein bulls when they were fed high- and lowenergy diets (Rotta et al., 2013). It is also numerically lower than those reported by NRC beef and dairy cattle (NRC, 1996, 2001) and by the BR-CORTE (Valadares Filho et al., 2010), which were $35 \%$ for low-energy diets and $47 \%$ for high-energy diets (below or above $50 \%$ of concentrate in the diet). The $k_{\mathrm{g}}$ depends on the proportions of retained energy in the form of protein and fat; thus, an estimate of $k_{\mathrm{g}}$ should take into account the composition of gain. When $k_{\mathrm{g}}$ was calculated by taking into account RE as protein (Marcondes et al., 2013), the $k_{\mathrm{g}}$ was $34.4 \%$.

\section{Protein Requirements}

In this study, the observed $\mathrm{MP}_{\mathrm{M}}$ was $3.05 \mathrm{~g}$ of protein $/ \mathrm{kg}$ of $\mathrm{BW}^{0.75}$. The NRC beef cattle (NRC, 1996) adopted a value of $3.80 \mathrm{~g}$ of protein $/ \mathrm{kg}$ of $\mathrm{BW}^{0.75}$ for $\mathrm{MP}_{\mathrm{M}}$ from the Wilkerson (1993) study. The $\mathrm{MP}_{\mathrm{M}}$ that was adopted by the INRA system (INRA, 1988) and by the AFRC system (AFRC, 1993) were 3.25 and $2.30 \mathrm{~g}$ of protein $/ \mathrm{kg}$ of $\mathrm{BW}^{0.75}$, respectively. The $\mathrm{MP}_{\mathrm{M}}$ found for Holstein $\times$ Gyr bulls in another study was $2.72 \mathrm{~g}$ of protein $/ \mathrm{kg}$ of $\mathrm{BW}^{0.75}$ (Rotta et al., 2013). Although our result for $\mathrm{MP}_{\mathrm{M}}$ was close to previous values, it generated a lower value of estimate of $\mathrm{MP}_{\mathrm{M}}$ compared with the NRC dairy cattle (NRC 2001) and BR-CORTE (Valadares Filho et al., 2010) systems. Thus, we suggest that our estimates of $\mathrm{MP}_{\mathrm{M}}$ should be used for crossbred (Holstein $\times$ Gyr) growing cattle (Appendix).

Regarding $\mathrm{NP}_{\mathrm{G}}$, when taking into account a bull that weighs $250 \mathrm{~kg}$ and with $1 \mathrm{~kg}$ of $\mathrm{ADG}$, the estimated $\mathrm{NP}_{\mathrm{G}}$ from Equation [20] was about $187 \mathrm{~g} / \mathrm{d}$ (Appendix). This $\mathrm{NP}_{\mathrm{G}}$ was greater than that suggested by the BR-CORTE for Nellore $\times$ Bos taurus bulls (Valadares Filho et al., 2010) and the NRC beef and dairy cattle (NRC, 1996, 2001). This result is valid because both systems used finishing cattle $(>300 \mathrm{~kg}$; less protein demand) to generate their estimates of protein requirements, whereas in our study, animals were in their growth stage (186 to $285 \mathrm{~kg}$, on average; greater protein demand).

The value of $k$ observed in this study was $35.7 \%$, which was about $24 \%$ lower than the $k$ proposed by the BR-CORTE (Valadares Filho et al., 2010), which was $46.9 \%$ for animals with SBW >350 kg, and about $40 \%$ lower for animals with SBW $<350 \mathrm{~kg}$. Similarly, it was numerically lower than the $k$ recommended by the NRC dairy cattle (NRC, 2001) for heifers or steers with equivalent SBW $<478 \mathrm{~kg}$ (Appendix). The $k$ may be mostly related to the quality of MP (Oldham, 1987).

\section{CONCLUSIONS}

Overall, the energy requirement estimates for crossbred Holstein $\times$ Gyr growing bulls were intermediate compared with those from the NRC system, which used British beef purebreds (also used for Holstein), and the more recently developed BR-CORTE system that used beef crossbreeds (Bos taurus $\times$ Bos indicus). Estimates of protein requirements, however, were generally numerically greater than those of the NRC and BRCORTE systems. We recommend use of the estimates of energy and protein requirements presented herein to achieve balanced diets for growing Holstein $\times$ Gyr bulls. However, even though our observations deviate from the NRC or BR-CORTE models, we cannot claim that our estimates of nutrient requirements for crossbreds are statistically different from those for purebreds (Holstein); further studies are necessary to determine the magnitude of those differences. This study evaluated the estimates of energy and protein requirements of crossbred (Holstein $\times$ Gyr) cattle and is one of only a few that exist in the literature. Further experiments evaluating the nutrient requirements of Holstein $\times \mathrm{Gyr}$ cattle, including animals of different ages and sexes, 
should be considered in order to generate a database to develop a nutrient requirement system for dairy breeds that are used in tropical regions.

\section{ACKNOWLEDGMENTS}

The results from this study are part of the results of the project "Nutrição de Precisão" of EMBRAPA (Empresa Brasileira de Pesquisa Agropecuária, Juiz de Fora, Brazil). The authors gratefully acknowledge the funding support from $\mathrm{CNPq}$ (Conselho Nacional de Desenvolvimento Científico e Tecnológico, Brasília, Brazil), FAPEMIG (Fundação de Amparo à Pesquisa do Estado de Minas Gerais, Belo Horizonte, Brazil), CAPES (Coordenação de Aperfeiçoamento de Pessoal de Nível Superior, Brasília, Brazil), and EMBRAPA. The first author gratefully acknowledges CAPES for the doctorate scholarship. Authors also acknowledge advice from Professor S. C. Valadares Filho and Professor M. L. Chizzotti.

\section{REFERENCES}

AFRC. 1993. Energy and Protein Requirements of Ruminants. Agricultural and Food Research Council/CAB International, Wallingford, UK.

Almeida, M. I. V., C. A. A. Fontes, F. Q. Almeida, S. C. Valadares Filho, and O. F. Campos. 2001. Conteúdo corporal e exigências líquidas de energia e proteína de novilhos mestiços Holandês $\times$ Gir em ganho compensatório. Rev. Bras. Zootec. 30:205-214. https:// doi.org/10.1590/S1516-35982001000100029.

AOAC. 1990. Official Methods of Analysis. 15th ed. Assoc. Off. Anal. Chem., Washington, DC.

Chen, X. B., Y. K. Chen, M. F. Franklin, and W. J. Shand. 1992. The effect of feed intake and body weight on purine derivative excretion and microbial protein supply in sheep. J. Anim. Sci. 70:1534-1542.

Chen, X. B., and M. J. Gomes. 1992. Estimation of microbial protein supply to sheep and cattle based on urinary excretion of purine derivative-An overview of technical details. International Feed Research Unit, Rowett Research Institute, Aberdeen, UK.

Clark, J. H., K. C. Olson, T. B. Schmidt, M. L. Linville, D. O. Alkire, D. L. Meyer, G. K. Rentfrow, C. C. Carr, and E. P. Berg. 2007. Effects of dry matter intake restriction on diet digestion, energy partitioning, phosphorus retention, and ruminal fermentation by beef steers. J. Anim. Sci. 85:3383-3390. https://doi.org/10.2527/ jas.2006-741.

Costa e Silva, L. F., S. C. Valadares Filho, T. E. Engle, P. P. Rotta, M. I. Marcondes, F. A. S. Silva, E. C. Martins, and A. T. Tokunaga. 2015. Macrominerals and trace element requirements for beef cattle. PLoS One 10:e0144464. https://doi.org/10.1371/journal. pone. 0144464

CSIRO. 2007. Nutrient Requirements of Domesticated Ruminants. Commonwealth Scientific and Industrial Research Organisation (CSIRO), Collingwood, Australia.

Doreau, M., and A. Diawara. 2003. Effect of level of intake on digestion in cows: Influence of animal genotype and nature of hay. Livest. Prod. Sci. 81:35-45. https://doi.org/10.1016/S03016226(02)00227-0.

Embrapa. 2009. Raças e tipos de cruzamentos para produção de leite. Circular Técnica CT 98. Empresa Brasileira de Pesquisa Agropecuária. Accessed Jan. 14, 2015. http://www.cnpgl.embrapa. br/totem/conteudo/Melhoramento_genetico_e_racas/Circular_
Tecnica/CT98_Racas_e_tipos_de_cruzamentos_para_producao_ de_leite.pdf.

Ferrell, C. L., and T. G. Jenkins. 1998. Body composition and energy utilization by steers of diverse genotypes fed a high-concentrate diet during the finishing period: II. Angus, Boran, Brahman, Hereford, and Tuli sires. J. Anim. Sci. 76:647-657. https://doi. org $/ 10.2527 / 1998.762647 x$.

Garrett, W. N. 1980. Energy utilization by growing cattle as determined by 72 comparative slaughter experiments. Energy Metab. Proc. Symp. 26:3-7.

INRA. 1988. Alimentation des bovines, ovins, et caprins. Institut National de la Recherche Agronomique (INRA), Paris, France.

Kleiber, M. 1961. The Fire of Life. An Introduction to Animal Energetics. John Wiley, New York, NY.

Lofgreen, G. P., and W. N. Garrett. 1968. A system for expressing net energy requirements and feed values for growing and finishing beef cattle. J. Anim. Sci. 27:793-806.

Marcondes, M. I., and A. L. Silva. 2015. Exigências nutricionais de animais lactentes. Pages 59-87 in Do Campus para o Campo: Tecnologia para Produção de Carne de Bovinos de Origem Leiteira. J. N. M. Neiva, A. C. G. R. Neiva, J. Restle, and A. Pedrico, ed. Suprema Gráfica e Editora, Araguaina, Brazil.

Marcondes, M. I., L. O. Tedeschi, S. C. Valadares Filho, and M. P. Gionbelli. 2013. Predicting efficiency of use of metabolizable energy to net energy for gain and maintenance of Nellore cattle. J. Anim. Sci. 91:4887-4898. https://doi.org/10.2527/jas.2011-4051.

NRC. 1984. Nutrient Requirements of Beef Cattle. 6th rev. ed. National Academy Press, Washington, DC.

NRC. 1996. Nutrients Requirements of Beef Cattle. 7th rev. ed. National Academy Press, Washington, DC.

NRC. 2001. Nutrients Requirements of Dairy Cattle. 7th rev. ed. National Academy Press, Washington, DC.

Oldham, J. D. 1987. Efficiencies of amino acids utilization. Pages 171186 in Feed Evaluation and Protein Requirements Systems for Ruminants. R. Jarrige and G. Alderman, ed. Luxembourg. CEC, Luxembourg.

Owens, F. N., and A. L. Goetsch. 1986. Digesta passage and microbial protein synthesis. Pages 196-223 in Control of Digestion and Metabolism. L. P. Milligan, W. L. Grovum, and A. Dobson, ed. Prentice-Hall, Englewood Cliffs, NJ.

Pereira, R. J., D. R. Ayres, L. El Faro, A. E. Vercesi Filho, R. S. Verneque, and L. G. de Albuquerque. 2013. Genetic parameters for production traits of dairy Gyr (Bos indicus) $\times$ Holstein cattle estimated with a random regression model. Livest. Sci. 158:24-31. https://doi.org/10.1016/j.livsci.2013.10.003.

Rotta, P. P., S. C. Valadares Filho, E. Detmann, L. F. Costa e Silva, M. F. Paulino, M. I. Marcondes, A. A. G. Lobo, and F. A. C. Villadiego. 2014. Digesta sampling sites and marker methods for estimation of ruminal outflow in bulls fed different proportions of corn silage or sugar cane. J. Anim. Sci. 92:2996-3006. https://doi. org/10.2527/jas.2013-7364.

Rotta, P. P., S. C. Valadares Filho, E. Detmann, L. F. Costa e Silva, F. A. C. Villadiego, E. M. G. Burgos, and F. A. S. Silva. 2013. Nutrient requirements of energy and protein for Holstein $\times$ Zebu bulls finished in feedlot. Semin. Cienc. Agrar. 34:2523-2534. https:// doi.org/10.5433/1679-0359.2013v34n5p2523.

Sniffen, C. J., D. J. O'Connor, P. J. Van Soest, D. G. Fox, and J. B. Russell. 1992. A net carbohydrate and protein system for evaluating cattle diets: Carbohydrates and protein availability. J. Anim. Sci. 70:3562-3577.

Tedeschi, L. O., C. Boin, D. G. Fox, P. R. Leme, G. F. Alleoni, and D. P. D. Lanna. 2002. Energy requirement for maintenance and growth of Nellore bulls and steers fed high-forage diets. J. Anim. Sci. 80:1671-1682.

Tedeschi, L. O., D. G. Fox, and P. J. Guiroy. 2004. A decision support system to improve individual cattle management. 1. A mechanistic, dynamic model for animal growth. Agric. Syst. 79:171-204. https://doi.org/10.1016/S0308-521X(03)00070-2.

Turner, J. W. 1980. Genetic and biological aspects of Zebu adaptability. J. Anim. Sci. 50:1201-1205. 
Valadares Filho, S. C., M. I. Marcondes, M. L. Chizzotti, and P. V. R. Paulino. 2010. Nutrient Requirements of Zebu Beef Cattle-BRCORTE. Suprema Gráfica e Editora, Visconde do Rio Branco, MG, Brazil. http://www.brcorte.com.br/br/.

Van Soest, P. J., J. B. Robertson, and B. A. Lewis. 1991. Methods for dietary fiber, neutral-detergent fiber and nonstarch polysaccharides in relation to animal nutrition. J. Dairy Sci. 74:3583-3597.

Wilkerson, V. A., T. J. Klopfenstein, R. A. Britton, R. A. Stock, and P. S. Miller. 1993. Metabolizable protein and amino acid requirements of growing cattle. J. Anim. Sci. 71:2777-2784.

\section{APPENDIX}

A spreadsheet (xlsx format) titled "Comparison of energy and protein requirements estimates of crossbred
Holstein $\times$ Gyr growing bulls with estimates from NRC (1996, 2001) and BR-CORTE (Valadares Filho et al., 2010)" is available as supplementary material (https:// doi.org/10.3168/jds.2016-11414). The included spreadsheet as supporting information can be used to determine energy and protein requirements for maintenance and growth using the equations determined in this study, the Nutrient Requirements of Dairy Cattle (NRC, 2001), and the BR-CORTE: Nutrient Requirements of Zebu Beef Cattle (Valadares Filho et al., 2010) to compare their estimates using different BW and BW gain. 